\title{
Register and Layout in Epistolary Judeo-Arabic
}

\author{
ESTHER-MIRIAM WAGNER \\ Woolf Institute and University of Cambridge, Cambridge, UK \\ E-mail:emw36@cam.ac.uk
}

\begin{abstract}
Medieval letters from the Cairo Geniza can be broadly classified into private, official, or mercantile correspondence, and all use particular linguistic registers. Official correspondence, for example, shows abundant code switching into Hebrew and the employment of high-style versus lower-style prose. Mercantile letters actively avoid Hebrew and emulate supraconfessional Arabic writing standards. Private letters typically display more colloquial and less standardized forms than other genres and are more often written in crude handwriting. Among these private letters, we find one written by or for women that share common features of colloquiality and less standardization even when they are transcribed by male scribes. Linguistic registers are also influenced by the time and place in which they are written, and comparing Geniza letters from different areas and time periods exposes geographic and chronological characteristics. For example, North African letters tend to be linguistically more conservative, and Babylonian and Egyptian letters show differences in layout and style. Throughout the medieval period, orthographic, grammatical, lexical, and stylistic changes in the letters reflect social and economic evolution over time. The principal trend is a distinct move away from prescriptive Arabic linguistic norms from the late twelfth century on.
\end{abstract}

Keywords Epistolary Judeo-Arabic · Linguistic registers

Our understanding of Judeo-Arabic Geniza letters has increased exponentially in the past four decades, thanks to Goitein's A Mediterranean Society. ${ }^{1}$ This seminal work caused a shift of Geniza research toward documentary materials as opposed to the earlier scriptural and literary focus. Previously, catalogers often merely described a fragment as letter. Now, scholars are usually able to give a good idea of the temporal and geographic origins and general purposes of Geniza correspondence after quick analyses of their layout, script, and linguistic forms.

An important part of these analyses is register. A linguistic register is a variety of language that is used by a certain group of people or in particular social settings and influenced by factors such as audience and purpose. Linguistic registers are perhaps most striking in speech, where they manifest themselves in youth speak, slang, or technical argots, and more subtly in the way people's communication changes whether their interlocutors are elderly

\footnotetext{
${ }^{1}$ S. D. Goitein, A Mediterranean Society: The Jewish Communities of the Arab World as Portrayed in the Documents of the Cairo Genizah, 6 vols. (Berkeley and Los Angeles, 1967-93).
} 
relatives, dear friends, professional superiors, or possess a limited command of a language. Perhaps less obvious in comparison to speech, linguistic variation due to change in register is equally significant in written language: texts of poetry, instruction manuals, belles lettres, academic writing, or utilitarian prose all show very different forms of language.

Within utilitarian prose from the Cairo Geniza, registers vary between legal documents, accounts, and letters. In epistolary writing, we have to distinguish carefully between letters written by members of different genders, professions, or religions and between those written in a private, official, or mercantile context. It is equally important to consider the relationship between writers and addressees. Is a letter written in the context of a family, within a business partnership, between friends, or between distant acquaintances? All these factors influence the register in which a letter is written-its language, formulas, and style.

\section{Merchants versus Dignitaries}

Letters in the Geniza can be broadly classified as mercantile, intracommunal, or private. Striking differences are observed when we compare letters written by traders to those by community leaders corresponding about communal or religious matters. For various reasons relating to speed of writing, care, level of literacy, and purpose of the correspondence, the act of writing business letters was different from that of composing, for example, well-thought-out community missives, which appear to have undergone a process of copying and editing, or letters written for the purpose of relaying matters pertaining to communal or religious affairs. ${ }^{2}$ Parkes has described the linguistic behavior of traders as "pragmatic literacy," as opposed to literacy of a more scholarly or "cultivated" nature. ${ }^{3}$ In the Geniza letters, we see this particular kind of literacy in the relatively simple format of typical business correspondence. Many mercantile letters follow a specific order of protocol and share an inventory of similar phrases. Compared to them, letters of educated dignitaries,

\footnotetext{
${ }^{2}$ For the peculiarities of business correspondence, see Esther-Miriam Wagner, "The SocioLinguistics of Judaeo-Arabic Mercantile Writing," in Merchants of Innovation: The Languages of Traders, ed. Esther-Miriam Wagner, Bettina Beinhoff, and Ben Outhwaite (Berlin, 2017), 68-86. The differences between a first draft and a final copy of a community missive can be seen in Dotan Arad and Esther-Miriam Wagner, "The Preacher Who Speaks Like a Parrot: Two Versions of a Letter by R. Joshua ha-Nagid,” Taylor-Schechter Genizah Research Unit, University of Cambridge, Fragment of the Month, January 2013, http://www.lib.cam.ac. uk/Taylor-Schechter/fotm/january-2013/index.html.

${ }^{3}$ Malcolm Parkes, "The Literacy of the Laity," in The Mediaeval World, ed. David Daiches and Anthony Thorlby (London, 1973), 555-77, 555.
} 
such as Daniel b. 'Azarya, employ complicated metaphor and flowery style, resembling highbrow literature, as can be seen in the examples offered below. ${ }^{4}$

Within a single writer's repertoire, we can observe great variations in style depending on the purpose of a given letter and the writer's relationship with the addressee. One decisive factor in the variation of registers is constituted by how many Hebrew elements are incorporated into the Judeo-Arabic text. Such insertions often come in the form of biblical citations that reference something the writer wants to express, such as "that he is loved by every heart and every soul" (an allusion to Deut. 6:5) (T-S 24.56r, line 39), ${ }^{5}$ or in the form of polite formulas at the beginning of a letter, such as שלומך חשובנו ויקירנו خ עלי הכהן הפרנס, "Peace to you, our esteemed and beloved Rabbi 'Eli ha-kohen ha-parnas" (T-S 10J9.20, line 1). Often, such polite formulas are also given before or after the names of certain people, such as פהו יעודדהו מגננו קד סברה, "and he, may his shield strengthen him, just examined it" (T-S 24.56r, line 11). In some sentences, we find a macaronic style of code switching

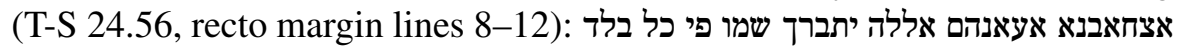

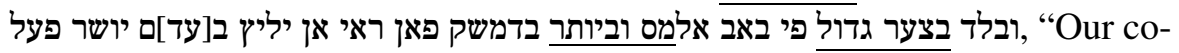
religionists-may God, blessed be his name, support them-in every single country are in great distress because of the epidemic, in particular in Damascus. If he thinks that he should speak on their behalf, then he should do [it]!"6

Wagner and Connolly have investigated the variation of code switching between Arabic and Hebrew within individual Geniza authors and different genres of Geniza letters. ${ }^{7}$ Part of their investigation focuses on the correspondence left behind by the dignitary Daniel b. 'Azarya, which provides a suitable case study because of the large number and breadth of topics of his letters. Their research demonstrates that an individual writer such as Daniel b. 'Azarya would vary the Hebrew content of his letters according to type of correspondence and also indicates that Daniel b. 'Azarya seems to have been very much aware of which linguistic register was appropriate for which audience and purpose. Wagner and Connolly selected ten of his letters and,

\footnotetext{
${ }^{4}$ For some of Daniel b. 'Azarya's high-style letters, see T-S 24.56 and T-S 13J26.18, edited in Moshe Gil, Palestine during the First Muslim Period (634-1099) (in Hebrew), 3 vols. (Tel Aviv, 1983), 2:655-62.

${ }^{5}$ The Hebrew is underlined here and in all subsequent examples.

${ }^{6}$ All examples are from Esther-Miriam Wagner and Magdalen Connolly, "Code-Switching in Judaeo-Arabic Documents from the Cairo Geniza," Multilingua 37, no. 1 (January 2018): $1-23$.

${ }^{7}$ See Wagner and Connolly, "Code-Switching in Judaeo-Arabic Documents."
} 
Table 1. Hebrew component in the letters of Daniel b. 'Azarya

\begin{tabular}{lll}
\hline Letter & Main content & Total \% of Hebrew words \\
\hline 1. T-S 10J25.2 & Religious & 31.6 \\
2. T-S 10J9.20 & Religious & 39.0 \\
3. Bodl. Heb.a.3.17 & Communal & 14.6 \\
4. T-S 24.56 & Communal & 12.0 \\
5. T-S 13J25.3 & Communal & 26.9 \\
6. ENA 4046.1 & Communal & 23.4 \\
7. T-S 13J8.8 & Communal/personal & 6.1 \\
8. T-S 13J26.18 & Communal/trade & 6.0 \\
9. T-S 13J26.2 & Trade & 1.4 \\
10. T-S 10J9.28 & Personal & 17.9 \\
\hline
\end{tabular}

Source. Esther-Miriam Wagner and Magdalen Connolly, "Code-Switching in Judaeo-Arabic Documents from the Cairo Geniza," Multilingua 37, no. 1 (January 2018): 1-23, 12.

before conducting the statistical linguistic analysis, classified them according to their main content (religious, communal, trade). They then provided the total percentage of Hebrew words within the respective Judeo-Arabic letters (see table 1).

As can be seen in the table, the letters with mostly religious content (letters 1 and 2) show the highest Hebrew content, between 30 and 40 percent. Interestingly, Daniel b. 'Azarya also refrains from using Arabic script in those letters, which is a frequent feature in all the other letters referenced in the table, indicating that he thought the use of Arabic script was not appropriate in a religiously framed context. Communal letters 3-6 show variation of Hebrew content between 12 and 27 percent. Letters focusing on personal matters appear to show less Hebrew in comparison with communal letters, with letter 10 displaying 18 percent of Hebrew code switching, while letter 7, with mixed communal and personal content, has only 6 percent Hebrew. The sharpest drop can be seen in the mercantile letter 9, with only 1.5 percent Hebrew content, while letter 8 , with mixed communal and trade content, has a Hebrew percentage of 6 percent.

Code switching to Hebrew thus was most common in letters with content marked as Jewish - the religious letters show the highest Hebrew content. As perhaps expected, letters for communal purposes display fewer cases of code switching to Hebrew, although they still are marked as Jewish by frequent code switching to Hebrew. Mercantile letters, on the other hand, employ only a minimum of Hebrew and thus avoid phraseology marked as Jewish.

Daniel b. 'Azarya's business writing is very much in accordance with what we see in letters composed by other merchants. An abbreviated table from Wagner and Connolly with data from ten randomly chosen traders' letters, 
Table 2. Hebrew component in mercantile letters

Letter

1. T-S 8.12

2. T-S $8 \mathrm{~J} 18.33$

3. T-S $13 \mathrm{~J} 17.11$

4. T-S 13J15.9

5. T-S $13 \mathrm{~J} 19.29$

6. T-S 16.163

7. T-S Misc. 25.62

8. T-S NS 308.119

9. T-S $10 \mathrm{~J} 11.23$

10. T-S 13J19.20
Total \% of Hebrew words
0.8
0
1.5
0.4
1.0
0.4
1.9
0.4
0.5
17.9

Source. Esther-Miriam Wagner and Magdalen Connolly, "Code-Switching in Judaeo-Arabic Documents from the Cairo Geniza," Multilingua 37, no. 1 (January 2018): 1-23, 10.

written by ten different authors, shows the following percentages of Hebrew content within the Judeo-Arabic (see table 2).

As can be seen, letters 1-9 display hardly any Hebrew content, normally not exceeding 2 percent of the total word count in the letters, even though all were addressed to fellow Jewish businessmen. Wagner and Connolly have also shown that those few Hebrew phrases that do occur belong to a very small repertoire of particular phrases, such as the final good-bye greeting עקב ושלום, "reward and peace," or the pious formula נני, "his soul is rested" (i.e., deceased) given after names. ${ }^{8}$

Mercantile correspondence also exhibits linguistic characteristics owing both to the education of merchants and to the circumstances of their acts of writing. Naturally, educated merchants writing to particular addressees with whom they enjoyed intellectual exchanges were also capable of writing in a high literary style. The letters of Halfon b. Netan'el to his beloved and well-educated friend the poet Judah ha-Levi are examples of such elevated correspondence. ${ }^{9}$ Another example is the writer of letter 10 in table 2 above, Yeshu'a b. Ismā'îl al-Makhmūrī. His employment of Hebrew phrases stands out among all other merchants' letters and does not fit with the rest of the data for business correspondence. Fortunately, the personal circumstances of Yeshu'a b. Ismā'îl give us a good idea of the reasons of his idiosyncratic behavior. We know that he studied with the most famous rabbi of the time in his youth and that he was generally an extremely well-read man. Yet, as we

\footnotetext{
${ }^{8}$ Wagner and Connolly, "Code-Switching in Judaeo-Arabic Documents," 10-11.

${ }^{9}$ See, e.g., T-S 24.47, edited in S. D. Goitein, Mordechai Akiva Friedman, and Amir Ashur, Halfon the Travelling Merchant Scholar: Cairo Geniza Documents (India Book IV/B) (in Hebrew), 2 vols. (Jerusalem, 2013), 2:500-513.
} 
have seen in the writing behavior of Daniel b. 'Azarya, even a well-read man capable of writing in all sorts of highbrow registers could choose not to make use of more literary language in a mercantile context. So other sociolinguistic characteristics must have influenced Yeshu'a's writing choices.

We find valuable clues in Jessica Goldberg's description of Yeshu'a, whom she calls "the difficult man." She explains that he "left many an irritated trace in the Geniza records" and that his "letters reveal an attitude toward his fellow merchants that is a compound of suspicion and a sense of ill-use (occasionally leavened by paranoia), expressing itself in petty sniping, righteous indignation, sarcasm, and counter-attack by way of self-defense."10 As Wagner and Connolly have pointed out, a man with such character traits removes himself linguistically from his fellow merchants by choosing to code switch to Hebrew in his Judeo-Arabic frequently, providing him with an air of superiority. ${ }^{11}$

The examples and analyses offered above demonstrate that letter writers were following the conventions of style expected of correspondence of a particular genre. While well-schooled men of all professions could compose letters emulating literary norms when writing in a context where conveying one's education was important and erudite refinement carried high prestige, they would in most cases change to a more simplified register of language when writing in a domain associated with "pragmatic literacy."

\section{Geography and Chronology}

Registers are subject to the time and place in which texts are written, so comparing Geniza letters from different areas and time periods exposes geographic and chronological characteristics. Our investigations are hampered, however, by the lack of diachronic materials for all the different regions, and extended analyses are therefore possible only in particular time periods and specific regions. The eleventh century is a suitable time period, given the wealth of mercantile sources from North Africa and Egypt. Here, we can observe that the writers of North African correspondence, for example, appear to write in a more conservative, archaizing style than their Egyptian coreligionists. This expresses itself not only in their prolonged use of parchment in comparison to their more easterly counterparts, who were quicker to adopt paper as a writing material as it spread west over several centuries, but also linguistically. ${ }^{12}$ This can, for example, be observed in the more frequent

\footnotetext{
${ }^{10}$ Jessica L. Goldberg, Trade and Institutions in the Medieval Mediterranean: The Geniza Merchants and Their Business World (Cambridge, 2012), 120-21.

${ }^{11}$ Wagner and Connolly, "Code-Switching in Judaeo-Arabic Documents," 13.

${ }^{12}$ See Esther-Miriam Wagner, Linguistic Variety of Judaeo-Arabic in Letters from the Cairo Genizah (Leiden, 2010), 227-28.
} 
use of the Arabic or Hebrew-Aramaic basmala, "in the name of God," in Maghribi letters in comparison with Egyptian letters. In contemporary Muslim Arabic letters, kitāb $\bar{l}$, "my letter (to you)," starts to be regularly added to the introductory formula from the tenth century on, ${ }^{13}$ and it has caught on in eleventh-century Judeo-Arabic Egyptian letters, where it is the most frequent introductory word. Most of the eleventh-century Maghribi letters do not exhibit this innovation but instead follow the basmala with the older introduction atāla llāhu baqā'aka, "may God preserve your well-being." 14

Other phonological, morphological, and syntactic difference between Maghribi and Egyptian material can also be observed. For example, in Egypt, the spelling $\dot{\xi}$ for Classical Arabic $\dot{b}$ is much more common than $\dot{v}$, whereas Maghribi letters show both $\dot{\dot{v}}$ and $\dot{\dot{y}}$ as equally common, which could be interpreted as a conservative or archaizing feature, that is, a feature adhering more closely to the Classical Arabic writing patterns, by using the equivalent of $b$ rather than $ص$ as base, mirroring the Arabic alphabet. ${ }^{15}$ The Maghribi sources also appear to emulate Classical Arabic norms to a greater extent than do the Egyptian documents. The use of $\boldsymbol{\aleph}$ for Classical Arabic t $\bar{a}$ ' marbu $\bar{t} t a$, for instance, is much more common in Egyptian material than in Maghribi letters. ${ }^{16}$ Similarly, the spelling of alif derived from the Classical Arabic accusative -an occurs in Maghribi material after numerals, in place of a Classical Arabic $h \bar{a} l$ accusative and other accusatives, often set hypercorrectly, while in Egyptian letters it is found only in adverbial constructions. ${ }^{17}$ Superscripted alif is often written plene in Egyptian letters but mostly follows the Classical Arabic non-plene writing convention in the Maghrib. ${ }^{18}$ Morphologically, the internal passive is found more often in Maghribi letters than in Egyptian letters, where it has been replaced by the passive stem. ${ }^{19}$ On the syntactic level, the negation phrase lam + imperfect, which is marked as a Classical Arabic or higher standard form, appears much more often in the Maghribi (in 82 percent of past negations) than in the Egyptian letters (56 percent), while $m \bar{a}+$ perfect, considered less classical as it is also used in the dialects, is used in only 17 percent of the examples in the Maghrib but

\footnotetext{
${ }^{13}$ See Werner Diem, Arabische Geschäftsbriefe des 10.-14. Jahrhunderts aus der Österreichischen Nationalbibliothek in Wien (Wiesbaden, 1995), Arabische Privatbriefe des 9.-15. Jahrhunderts aus der Österreichischen Nationalbibliothek in Wien (Wiesbaden, 1996), and Arabische Briefe aus dem 10.-16. Jahrhundert (Berlin, 2011).

${ }^{14}$ Compare Wagner, Linguistic Variety, 99.

${ }^{15}$ Compare Wagner, Linguistic Variety, 28-32, 40.

${ }^{16}$ Compare Wagner, Linguistic Variety, 43-44, 51.

${ }^{17}$ Compare Wagner, Linguistic Variety, 47-50, 52.

${ }^{18}$ Compare Wagner, Linguistic Variety, 58-59.

${ }^{19}$ Compare Wagner, Linguistic Variety, 84-86, 228.
} 
in 43 percent of examples from the Egyptian letters. ${ }^{20}$ The Maghribi corpus that I analyzed also exhibits no examples of tanwin-derived constructions, such as [noun $+a n+$ adjective], [noun $+a n+$ attributive noun], and [noun $+a n+$ attributive clause with nongeneric referent], while, in the Egyptian sources, these construction types are attested frequently. ${ }^{21}$

A contrast between Babylonian and Fatimid Egyptian letters can be found in the dating formulas. In Egypt, the date in eleventh- and early twelfthcentury Judeo-Arabic letters, at least in mercantile correspondence, occurs in the introductory sentences and follows Classical Arabic style: the verbs baqiyya, "remain," and khalā, "pass," are used in conjunction with li- followed by numerals. ${ }^{22}$ In Babylonian letters, in contrast, the date appears at the end of the letter, without the Arabic verbal formulas. ${ }^{23}$ Byzantine sources appear to show $\boldsymbol{w}$ for $s$ more commonly than do letters from other regions. ${ }^{24}$

In the second half of the twelfth century, Egyptian letters undergo stylistic changes and adopt a different layout and writing style. ${ }^{25}$ Many changes appear to mirror writing patterns observable in eleventh-century Babylonian correspondence. The dating formulas become less sophisticated, the specific Arabic verbs used in the dating calculation are dropped, and the date moves to the end of the letter. Letters from the twelfth century on show increased code switching into Hebrew, even in correspondence dealing with business issues. ${ }^{26}$ Linguistic phenomena connected to the spoken language, which cannot be found in the eleventh-century letters, start to occur. For example, while no $b i$-imperfect forms occur in the eleventh-century letters, they start appearing in the thirteenth-century letters. Similarly, the eleventh-century letters contain only demonstrative pronouns from the Classical Arabic inventory, while the thirteenth-century material frequently shows vernacular

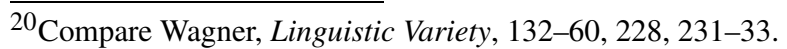

${ }^{21}$ Compare Wagner, Linguistic Variety, 103.

${ }^{22}$ Wagner, Linguistic Variety, 102-3.

${ }^{23}$ Esther-Miriam Wagner and Ben Outhwaite, “'These two lines': Hebrew and Judaeo-Arabic Letter-Writing in the Classical Genizah Period," in Beyond Free Variation, ed. Jennifer Cromwell and Eitan Grossman (Oxford, 2016), 314-32.

${ }^{24}$ Ben Outhwaite, "Byzantium and Byzantines in the Cairo Genizah: New and Old Sources," in Jewish Reception of Greek Bible Versions: Studies in Their Use in Late Antiquity and the Middle Ages, ed. Nicholas de Lange, Julia G. Krivoruchko, and Cameron Boyd-Taylor (Tübingen, 2009), 182-220, 214.

${ }^{25}$ See Wagner, Linguistic Variety, 117-75; and Esther-Miriam Wagner, "The Weakening of the Bourgeoisie: Social Changes Mirrored in the Language of the Genizah Letters," in Cambridge Genizah Studies I: Proceedings of the 1st International Conference on Genizah Studies, Westminster College, Cambridge 2007, ed. Ben Outhwaite and Siam Bhayro (Leiden, 2010), 343-55.

${ }^{26}$ For example, T-S $10 \mathrm{~J} 18.22$ and T-S 8J23.2, letters from the archive of the judge Elijah b. Zechariah that pertain almost exclusively to business matters. 
demonstratives, such as $d a$. Equally, the appearance of $m \bar{a}$ as a relative particle in the thirteenth-century letters is an indication of ongoing language change manifesting in the written language. Other phenomena that separate early (tenth- to eleventh-century) from later (twelfth- to thirteenth-century) medieval correspondence concern the increased use of plene spelling of vowels, the double spelling of $[\mathrm{w}]$ and $[\mathrm{y}] .^{27}$

In the thirteenth-century letters, the use of the negation particle lam decreases dramatically compared to eleventh-century letters, and the majority of examples use $m \bar{a}$ (74 percent), which occurs less frequently in the earlier material. In addition to the change in the frequency of use between the negation $m \bar{a}$ and lam, we also find change in the negations with lam itself. In Classical Arabic, lam can be used only with the imperfect and always expresses a past action. This prescriptive rule is obeyed in the eleventh-century letters. In the thirteenth-century letters, however, examples of lam + imperfect are used to express present action. There are even cases in which lam is constructed with the perfect. This is impossible in Classical Arabic, but such forms begin to appear more frequently in the thirteenth-century material and become the norm in Late Judeo-Arabic letters.

Some of these linguistic developments may reflect a growing influence of Babylonian norms, but the general linguistic thrust of thirteenth-century epistolary writing probably also indicates significant changes in the social environment and in the relationship between the Jewish and the Muslim communities and may be connected to the slow breakdown of polite Arabic culture after the demise of the Fatimid empire. ${ }^{28}$

Particular lexical features can be observed in the vocabulary of letters. A handy chronological shibboleth can be found in the verbs for the expression "to send (a letter)." 29 In eleventh- and twelfth-century material, the verb nafadha is used for such purposes. ${ }^{30}$ The writers of the thirteenth-century material employ the verb sayyara to express "sending." In later material, the verb arsala is used. In undated texts-in particular in crude letters-the choice of word can be the basis for a rough chronological attribution.

Similarly, the words mamlük, "servant," and makhdüm, "master," used for designating the sender and the addressee, respectively, enter epistolary address only from the twelfth century on. Geoffrey Khan notes that these words

\footnotetext{
${ }^{27}$ This was first called Hebraized orthography in Benjamin Hary, "The Adaptations of Hebrew Script," in The World's Writing Systems, ed. Peter T. Daniels and William Bright (New York, 1996), 727-34, 732.

${ }^{28}$ Wagner, "The Weakening of the Bourgeoisie," 343-345, 354-55, and Linguistic Variety, 229-33.

${ }^{29}$ Wagner, Linguistic Variety, 107-8.

${ }^{30}$ While the word nafadha is used for the sending of letters and other light goods, hamala and also arsala are used in eleventh- and twelfth-century letters for the shipping of heavier goods.
} 
were introduced into petitions during the reign of al-Āmir (1101-30 CE) in the formula al-mamlūk yuqabbil al-ard, "the servant kisses the ground" (reflecting the actual practice of throwing oneself into the dirt before the caliph), and from there spread to polite letter writing. ${ }^{31}$ The whole formula itself can also be encountered in Jewish correspondence, another example of how court protocol and petition formularies influenced Jewish letter writing. ${ }^{32}$

\section{Crude-Hand Letters, Private and Women's Correspondence}

Letters written in crude handwriting pose the most difficulties when it comes to placing them in a temporal context, in particular as they often feature irregular orthography and phraseology, thus further complicating accurate dating. Many of these crude-hand letters are written in a private context, which is self-explanatory as people composing correspondence in a mercantile or official context would have had scribes available if they could not rely on their own handwriting or were not practiced enough in letter writing. Famous exceptions include the community leader Efraim b. Shemarya, whose frequent crude-hand letters are immediately recognizable for their lack of graphic aesthetics. $^{33}$

Overproportionally often, medieval Geniza letters written in a crude hand appear to be sent by and to women. ${ }^{34}$ This is connected to a number of issues, such as women's literacy, socioeconomic situation, access to scribes, and less need for prestige (and hence employment of scribes) as letters written by women are usually sent in a private context. Many of the crude-hand letters sent by women were probably dictated to family members who were less familiar with letter-writing conventions than professional writers would have been. Letters sent by and to women do, however, also show unusual features when written by experienced male scribes.

The reason why women's dictation shines through even in male scribes' writing is that, when male scribes are taking dictation from someone of a different gender and/or age group, their writing behavior changes. Alexander Bergs has shown that, in the English Paston letters, scribes alter the forms they employ if they write for their elders and, in particular, for their mothers

\footnotetext{
${ }^{31}$ Geoffrey Khan, "The Historical Development of Early Arabic Documentary Formulae," in Scribes as Agents of Language Change (Studies in Language Change, vol. 10), ed. EstherMiriam Wagner, Ben Outhwaite, and Bettina Beinhoff (Berlin, 2013), 199-215, 208.

${ }^{32}$ See varying forms of the formula in T-S 13J13.26/4f, T-S 13J21.5/1f, and T-S 12.575/1f.

${ }^{33}$ See, e.g., his letters T-S 13J16.20, T-S 13J36.14, and Mosseri VII.136.1.

${ }^{34}$ See Esther-Miriam Wagner, "Genizah Sociolinguistics: The Language of Women," in Language, Gender and Law in the Judaeo-Islamic Milieu, ed. Zvi Stampfer and Amir Ashur (Leiden, in press).
} 
by using more conservative forms than they would employ in their own writing, which would allow for more progressive language forms. ${ }^{35}$ The difference between Judeo-Arabic and English is that, in most European languages, women are known to use more standard forms than do men, who tend to use nonstandard expressions. Hence, the Paston writers would use conservative forms for their mothers. In the case of the linguistic dichotomy of Arabic (the spectrum of literary Arabic on one side and vernacular Arabic on the other), writing dictated by women is prone to show a higher proportion of colloquial forms as, for the scribes, there would be less need when writing for women to demonstrate the women's education in normative Arabic while there was perhaps a greater need to connect emotionally to the addressees of their writing. It is thus not necessarily women's literacy shaping the letter writing but the scribe's expectations. How does a man think a woman would write?

Studying Geniza letters dictated by women, I noticed more frequent deviations from normative contemporary standards of Judeo-Arabic in comparison to letters sent by men. With reservations due to the small sample size of studied material, I raised the possibility that women's letters generally show more deviations from the contemporary Judeo-Arabic writing conventions of the time than does comparative correspondence composed by men. ${ }^{36}$

I have suggested the letter L-G Arabic 2.129, written by a man but dictated by a female family member, as a good example. ${ }^{37}$ The unusual linguistic features in the letter include commonly plene spelled short vowels, mostly [u] and [i] such as in כנתי, "you were" (e.g., line 15), but also short [a] such as in מארת, "she went" (line 11). First singular $n$-imperfect forms occur, for example, in קאלת אנא נכון ממלוכה "she said: I am a slave" (line 16), and in אנא אבראהים נקבל ידיין אלשיך אבו אלחסן, "I, Ibrāhīm, kiss the hands of the elder Abū al-Hassan" (lines v5-v6), which additionally shows the tanwīn ידיי in a genitive construction, as does תבוסי עינין אם אסמעיל אכתי, "kiss the eyes of Umm Ismaīl, my sister" (line 25). The possessive particle bita', which typically appears only in Late Judeo-Arabic, can be found in סאעה וקופך עלי האדה אלאחרף תנפדי אלחלק בתאעי מע בנת כאלך סת נסרין , "quickly, when you read these lines, send my ring with your cousin Sitt Nisrīn" (lines 18-20). The article is spelled in assimilation in "the elder Abū al-Hassan" (line v13), although the rest of the letter shows the article in alshaykh in regular spelling, אלשיך. The phrase לם יציבהם ש, "nothing happened

\footnotetext{
${ }^{35}$ Alexander Bergs, "Linguistic Fingerprints of Authors and Scribes," in Letter Writing and Language Change, ed. Anita Auer, Daniel Schreier, and Richard J. Watts (Cambridge, 2015), 114-32, 124, 129.

${ }^{36}$ Wagner, "Genizah Sociolinguistics."

${ }^{37}$ Esther-Miriam Wagner, "The Language of Women: L-G Arabic 2.129," Taylor-Schechter Genizah Research Unit, University of Cambridge, Fragment of the Month, January 2015, http://www.lib.cam.ac.uk/Taylor-Schechter/fotm/january-2015/index.html.
} 
to them" (lines 8-9), may contain a misspelling of $\boldsymbol{w}$ for shay but could also indicate a form of the negation particle $-\check{s}$, which would be an extremely early example as it can normally be found only in Late Judeo-Arabic texts.

In a second case study, I analyzed four letters written by the same writer, Șadaqa b. 'Ayyāsh, a North African trader active in Qayrawān, Mahdiyya, and Alexandria, with special attention to their linguistic peculiarities. ${ }^{38}$ Two of these letters, T-S 13J23.14 and Bodl. MS Heb.d.66.15, were dictated by or written for a man, while the other two, T-S 12.261 and T-S 12.262, were dictated by or written for a woman.

The evidence from the letters suggests that plene spelling of short vowels occurs slightly more commonly in women's letters. One of the women's letters shows a spelling after the preposition $f i$ that may reflect a third singular masculine suffix:" אנא נערף אן הזא כאן אמלה פי "I know that this was his hope in it" (T-S 12.261, line 15), in a more unusual orthography.

Valuable points of comparison between the letters are the forms used for the first-person imperfect. In the letters by women, unambiguous forms of $n a f^{\prime} a l$ for the first singular imperfect appear in אנא נערף, "I know" (T-S 12.261, line 15), גית נלבס, "I came to dress" (T-S 12.261, line 20), , נקטע כתבי ענכם, "I cut my letters from you" (T-S 12.262, line 14), אני נתלד , "that I am perplexed" (T-S 12.262, line 14), and אנני נחאדתכם, "that I inform you" (T-S 12.262, line 15). ${ }^{40}$ Further forms - very likely first-person singular forms as inferred from the context—are נחב ונשתהי, "I would love and wish" (T-S 12.262, line 7), and לם נרא, "had I not seen" (T-S 12.262, line 13). These vernacular forms are all the more important if we compare them to the first singular imperfect forms that occur in one of Sedaqa's letters written for a man and composed at roughly the same time in North Africa, which shows overwhelmingly the type $a f$ 'al, such as ארגו, "I hope" (T-S 13J23.14, line 10), אעלמה a "I "I need to work them" (T-S 13J23.14, line 15), and, "I will know them" (T-S 13J23.14, line 25), although the type naf'al also occurs: לם נדכרהא, "I did not mention them" (T-S 13J23.14, line 17).

The colloquial verbal stem itfa "ala is used only in a woman's letter: אתערית, "I was naked" (T-S 12.261, line 21). An example of the relative particle an preceding an attributive clause, a substandard feature of Judeo-Arabic,

\footnotetext{
${ }^{38}$ Wagner, "Genizah Sociolinguistics." All four letters have been edited and translated in Moshe Gil, In the Kingdom of Ishmael (in Hebrew), 4 vols. (Tel Aviv, 1997), 2:458-72. All Gil's readings were checked against the original manuscripts.

${ }^{39}$ See also Joshua Blau, A Grammar of Mediaeval Judaeo-Arabic, 2nd enlarged ed. (in Hebrew) (Jerusalem, 1980), sec. 268b.

${ }^{40}$ For a discussion of naf'al, see Haim Blanc, "The nekteb-nektebu Imperfect in a Variety of Cairene Arabic," Israel Oriental Studies 4 (1974): 206-26; and Wagner, Linguistic Variety, 77-81.
} 
occurs in only one of the women's letters: אן דכלו אלי ווקת, "and when (lit. the time that) they came to me" (T-S 12.261, line 20).

Perhaps the most convincing argument for the existence of a particularly colloquial female register is provided by the use of vernacular vocabulary. In the letters dictated by women, we find a number of colloquial forms. For example, the question particle leysh, "why," is employed in T-S 12.261, line 9, and the demonstrative hon, "here," occurs in T-S 12.261, line 12. In contrast, Bodl. MS Heb.d.66.15, a letter that Ședaqa writes for himself and that is addressed to a member of the distinguished Tustarī family, shows phenomena that are distinctly noncolloquial and part of the literary, more Classical Arabic-informed registers: we find the counted in the accusative after numerals 20-99 (e.g., in lines 11 and 16), which is generally found only rarely in documentary Judeo-Arabic, and al-ukhrā is spelled אלאכרי as in Classical Arabic, with an additional marking of the Arabic reading sign damma above the alif to indicate the reading $[\mathrm{u}]$.

In short, the letters written for women appear to contain more Middle and Mixed Arabic elements than do those written for men, for example, in spelling, in the verbal stems, and in the lexicon. A main feature that sets the letters from women apart from the letters from men seems to be the use of colloquial forms that have distinct regional marking.

Using colloquial forms has to do with language immediacy; writers employ a less formal register to be able to communicate in a less formal setting and to connect more intimately with their readers. Emotions have been identified as an important sociolinguistic trigger for switches between registers or languages. In examples from eighteenth-century Arabic, we see that, when writers become aggressive, they are also more prone to use colloquial expressions. ${ }^{41}$ Colloquial phrases are thus often correlated to emotional pleas or outbursts (which makes them perhaps more commonly used in the context of private letters), and a modification in the formality of an epistolary register can be used as a tool to signal a change in immediacy between writer and reader. Hence, colloquial expressions can be employed both by scribes, who use them to convey intimacy between themselves and their readers, and by untrained writers, who do not know the corresponding high-variety equivalent to their spoken expressions.

Since the women represented in the Geniza corresponded mostly within families and rarely on an official level, it is thus natural to find more colloquial Judeo-Arabic. In addition, for the male family member or the male

\footnotetext{
${ }^{41}$ See Esther-Miriam Wagner and Mohamed Ahmed, "From Tuscany to Egypt: Eighteenth Century Arabic Letters in the Prize Paper Collections," Journal of Semitic Studies 62, no. 2 (Autumn 2017): 389-412, which deals with Arabic letters that were on a ship looted by English privateers in 1759.
} 
scribe taking dictation in a family context, there would be less need to render the colloquial speech he would be hearing into formal Arabic, something that he may have felt obliged to do when writing for a man in an official context.

It must be stressed that colloquial forms are not exclusively reserved for women's writing (although they seem to occur more commonly in that context). Men used vernacular language, too. In these cases, the occurrence of vernacular words is often connected to level of literacy. Yet, in particular sociolinguistic situations, very educated writers may employ colloquial forms, too, as a means to connect to their audience. This may be the case when they discuss very intimate matters with a close friend, dispense comfort, or address female family members. It is thus not only the gender of the writer that is decisive; the gender of the addressee is of equal importance. ${ }^{42}$

\section{Conclusion}

The main genres of medieval Judeo-Arabic epistolary writing from the Cairo Geniza are mercantile, official, and private letters, which show considerable variations in handwriting, layout, and linguistic register. Factors that influence the register in individual letters are the background, profession, and gender of both the writer and the addressee, their relationship to one another, the purpose of the correspondence, and the physical act of composing a letter. Official correspondence often displays a more carefully planned layout and less cursive handwriting, whereas mercantile letters are generally written in a more cursive style, with tighter line spacing and marginalia. Differences between mercantile and official correspondence also manifest themselves in the use of code switching into Hebrew and the employment of high-style versus lower-style prose. Private letters typically display more colloquial and less standardized forms than other genres and are more often written in crude handwriting. Among these private letters, we find many written by or for women, letters that share common features of colloquiality and less standardization even when they are written by male scribes. In fact, women's writing is shaped not only by the women's literacy but also, in the case of male scribes acting on women's behalf, by expectations of female (il)literacy. Further variations can be observed with regard to geographic origin: North African letters tend to be linguistically more conservative, whereas there are differences in dating formulas between Babylonian and Egyptian letters. Throughout the medieval period, diachronic linguistic changes in the

\footnotetext{
${ }^{42}$ For the same phenomenon in English, see Alexander Bergs, Social Networks and Historical Sociolinguistics: Studies in Morphosyntactic Variation in the Paston Letters (Berlin, 2005), 181-83.
} 
letters manifest at orthographic, grammatical, lexical, and stylistic levels, reflecting the social and economic changes of the time, with a distinct move away from earlier, prescriptive Arabic linguistic norms from the late twelfth century on.

Publisher's Note Springer Nature remains neutral with regard to jurisdictional claims in published maps and institutional affiliations.

Open Access This article is distributed under the terms of the Creative Commons Attribution 4.0 International License (http://creativecommons.org/licenses/by/4.0/), which permits unrestricted use, distribution, and reproduction in any medium, provided you give appropriate credit to the original author(s) and the source, provide a link to the Creative Commons license, and indicate if changes were made. 